\title{
Mortality and incidence of cancer among Swedish
} gas workers

\author{
P Gustavsson, Christina Reuterwall
}

\begin{abstract}
The mortality and incidence of cancer was studied among 295 workers at a Swedish gas production company. All men employed for at least one year between 1965 and 1972 were included in the study. The follow up period for mortality was 1966 to 1986 , and the incidence of cancer was followed up from 1966 to 1983. Expected numbers of deaths were based on local death rates among occupationally active men, the expected numbers of cancer were based on national statistics. The total mortality was increased, mainly due to an excess of deaths from circulatory diseases. The excess was larger after long follow up and after long employment periods. Two cases of cancer in the nose and nasal sinuses were found; there was no excess of lung cancer. Smoking habits were investigated for a subset of the cohort and did not differ from the average for men in large cities. The findings are discussed in relation to other studies of soot and combustion exposed workers.
\end{abstract}

Coal gas is produced by dry distillation of bituminous coal. Coke, the residue after distillation, is formed as a byproduct.

The Stockholm Gas Company has produced gas since the middle of the nineteenth century. The current plant started in 1893 and coal gas was produced in coke ovens from around 1918 to 1972 . Before 1918 the gas was produced in retorts and since 1972 gas has been produced by cracking of petroleum products. The coke ovens were similar to those in a coke plant and coke was an important byproduct. Around $150000000 \mathrm{~m}^{3}$ gas and 300000 metric tons coke were produced annually in the period 1950-70.

Gas and coke workers are exposed to gas and

Department of Occupational Medicine, Karolinska Hospital, Stockholm, Sweden

P Gustavsson

Division of Occupational Medicine, National Institute of Occupational Health, Solna, Sweden

C Reuterwall smoke from the ovens. The first study indicating an increased risk of cancer for gas workers was published in 1936, when Kuroda and Kawahata reported an excess of lung cancer at a Japanese gas plant. ${ }^{1}$ Excesses of cancer of the lung and bladder were later reported among 2449 British gas workers ${ }^{2}$ and an excess of lung cancer was also found in a small cohort of Danish gas workers. ${ }^{3}$ Several case reports indicate that gas workers are also at increased risk for skin cancer. Polycyclic aromatic hydrocarbons (PAH) have been pointed out as the most probable cause of the excess risks. ${ }^{4}$

The International Agency for Research on Cancer (IARC) evaluated the cancer hazards for gas production workers and concluded that there was sufficient evidence that coal tar from destructive distillation of coal in gas works causes skin cancer in man and there was also sufficient evidence that certain exposures in retort houses of older coal gasification processes are carcinogenic and give rise to lung cancer in man. ${ }^{4}$ There was limited evidence that such occupational exposures also cause bladder cancer. No data were available for exposures in newer processes.

The occupational exposures associated with coal gas production have several similarities with those in coke plants, where coke is produced for metallurgical purposes and gas is a byproduct. An excess of lung cancer was reported among 4661 workers in 12 coke plants in the United States and Canada. There was also a tendency towards increased mortality in cancer of the kidney and prostate..$^{5-8}$

An excess of lung cancer was found among 6767 English coke production workers $(\mathrm{SMR}=117)^{9}$ and among 1269 French coke production workers $($ SMR $=251) .^{10}$

An investigation of the mortality and incidence of cancer at a Swedish coke plant was first published in $1979^{11}$ and the study was updated in $1987 . .^{12}$ There was an increased mortality from ischaemic heart disease but no definite indications of an excess of lung cancer in this small cohort.

Thus there is strong evidence for an increased risk of lung cancer among coke and gas workers, possibly caused by exposure to PAH. In recent years an increased risk for atherosclerotic disease has also been reported among workers exposed to combustion products and PAH. Excesses of ischaemic heart disease were found among Swedish chimney 
sweeps, ${ }^{1314}$ Danish chimney sweeps, ${ }^{15}$ tar distillation workers ${ }^{16}$ and aluminium reduction plant workers. ${ }^{17}$

The aims of the present study were to evaluate the risk of cancer in a comparatively modern gas company and to investigate further the relation between exposure to PAH and atherosclerosis in man.

\section{EXPOSURE CONDITIONS AND WORK TASKS}

The exposure to benzo(a)pyrene $(\mathrm{BaP})$ was measured in the current plant by area sampling on top of the ovens. In 1964 a mean level of $4.3 \mu \mathrm{g} / \mathrm{m}^{3}$ of $\mathrm{BaP}$ was detected, (range $0.007-33 \mu \mathrm{g} / \mathrm{m}^{3}$ ). In 1965 lower levels were found, mean $0.52 \mu \mathrm{g} / \mathrm{m}^{3}$, range 0.021 $1.29 \mu \mathrm{g} / \mathrm{m}^{3} .{ }^{18}$ Calculations indicate that Swedish coke plants (including the current gas company) have had exposures of the same magnitude as in American plants. ${ }^{18}$

Generator gas for heating the coke ovens was produced in the steam and generator department. Generator gas contains around $30^{\circ}{ }_{\mathrm{o}}$ carbon monoxide.

In 1967 the carbon monoxide content in exhaled air was measured among the workers at the coke ovens and at the steam and generator central as a surrogate for carboxyhaemoglobin $(\mathrm{COHb})$ levels in blood. A mean level of $2^{\circ}{ }_{0} \mathrm{COHb}$ was found in 135 samples from 29 non-smoking workers at the generator central. Twelve per cent of the samples showed levels over $5^{\circ}{ }_{0} \mathrm{COHb}$, indicating a definite occupational exposure to carbon monoxide. In 561 samples from 63 non-smokers in the coke oven department the mean level was $0.4 \%$. Only $0.4 \%$ of these samples showed values over $5 \% \mathrm{COHb}$, indicating that only a few of these workers were exposed to carbon monoxide in significant amounts (unpublished data).

In the coke department coke was sorted, transported, and stored. The work was dusty but no hygienic measurements are available. The byproduct workers handled benzene; exposure levels are unknown. The workshop and maintenance workers have had intermittent exposures, since many of them have moved all over the plant. The outside workers transported coal from the harbour to the coke ovens and the workers at the department for sample preparation collected samples of coal and coke for quality control. All workers in the gas company were exposed to dust coated with PAHs in varying degrees.

\section{Study population and methods}

All men employed for at least one year between 1 January 1965 and 30 June 1972 were identified from company records. Data on work tasks and employment periods were recorded for all 300 identified individuals. Data on work tasks before 1965 were not available, however, and in calculating employment periods all workers were assumed to have worked in the same department before 1965 as they did at the beginning of that year. Exposure period was calculated as the period from actual start of employment until separation from employment or until 30 June 1972 when the coal gasification stopped.

Interviews were performed with a group of older workers and foremen in the workshop and maintenance departments regarding the smoking habits of the cohort members in these departments. Smoking data for $95 \%$ of the cohort members in these departments were obtained in this way.

Outcome was traced by a computerised register of the living population at Stockholm County Administration Board, death and burial books at the clerical parishes, and Stockholm City Archives. Underlying causes of deaths were obtained from Statistics Sweden and data on the incidence of cancer were obtained from the Swedish Cancer Registry. Mortality was investigated from 1966 to 1986 and the incidence of cancer from 1966 to 1983.

Four of the 300 cohort members had emigrated and one was never registered in Swedish population registers. These five individuals were excluded from the analyses. Table 1 shows the number of individuals and average employment periods in each department.

Expected numbers of deaths and cancers were computed according to the person-year method, counting years at risk for each individual, specific for five year age class and five year calendar time class. The OCMAP ${ }^{19}$ and EPILIN ${ }^{20}$ computer programs were used for the calculations.

The reference rates for mortality were based on the mortality in "Greater Stockholm," a geographical area including Stockholm City and the surrounding communities. A second set of reference rates was also calculated, based on the mortality among occupationally active men. The rates were derived by combining the local mortality data with information on the mortality among employed and not employed individuals obtained in the national census of $1960 .^{21}$ This second set of rates reflects the local mortality

Table 1 Number of individuals and mean employment period at the departments in the gas company (five had worked in more than one department)

\begin{tabular}{lrrr}
\hline & \multicolumn{3}{c}{ Employment period } \\
\cline { 2 - 4 } Department & No & Mean & Median \\
\hline Coke ovens & 66 & $11 \cdot 9$ & 5 \\
Steam and generator central & 12 & $15 \cdot 1$ & 15 \\
Coke department & 55 & $14 \cdot 7$ & 6 \\
Byproduct workers & 18 & $21 \cdot 8$ & 24 \\
Workshop and maintenance workers & 101 & 18.7 & 20 \\
Outside workers & 42 & $14 \cdot 7$ & 12 \\
Sample preparation & 6 & $22 \cdot 8$ & 22 \\
Total & 295 & 16.3 & 15 \\
\end{tabular}

*This group comprised metal workers (including welders and blacksmiths), electricians, sheet metal workers, plumbers, instrument mechanics, carpenters, and bricklayers. 
Table 2 Mortality among the gas workers between 1966 and 1986. Reference rates based on local mortality and local mortality adjusted for occupational activity (5199.1 person-years of observation)

\begin{tabular}{|c|c|c|c|c|c|c|c|}
\hline \multirow[b]{2}{*}{ Cause of death (ICD 8) } & \multirow[b]{2}{*}{ Observed } & \multicolumn{3}{|c|}{ Stockholm, employed } & \multicolumn{3}{|c|}{ Stockholm, general population } \\
\hline & & $\operatorname{Exp}$ & $S M R$ & $95^{\circ} \mathrm{CI}$ & $\operatorname{Exp}$ & $S M R$ & $95 \% C I$ \\
\hline $\begin{array}{l}\text { All causes (0-999) } \\
\text { All malignant tumours }(140-209) \text { : } \\
\text { Oesophageal cancer }(150) \\
\text { Stomach cancer }(151) \\
\text { Bowel cancer }(152-153) \\
\text { Rectal cancer }(154) \\
\text { Liver cancer }(155) \\
\text { Pancreatic cancer (157) } \\
\text { Lung cancer (162) } \\
\text { Prostatic cancer }(185) \\
\text { Bladder cancer }(188) \\
\text { Kidney cancer }(189) \\
\text { Brain tumours (191) } \\
\text { Haematopoietic cancer (200-209) } \\
\text { Nervous diseases (320-389) } \\
\text { Circulatory diseases(390-458): } \\
\text { Ischaemic heart disease (410-414) } \\
\text { Cerebrovascular diseases (430-438) } \\
\text { Respiratory diseases (460-519): } \\
\text { Asthma, bronchitis, emphysema (490-493) } \\
\text { Digestive diseases (520-577): } \\
\text { Liver cirrhosis (571) } \\
\text { Genitourinary diseases (580-629) } \\
\text { Violent death and intoxication (E800-E999) } \\
\text { Suicide (E950-E959) }\end{array}$ & $\begin{array}{r}84 \\
22 \\
2 \\
2 \\
2 \\
1 \\
1 \\
1 \\
4 \\
4 \\
2 \\
0 \\
1 \\
0 \\
0 \\
39 \\
28 \\
6 \\
4 \\
2 \\
4 \\
1 \\
0 \\
11 \\
3\end{array}$ & $\begin{array}{c}66 \cdot 29 \\
19 \cdot 32 \\
\text { NA } \\
\text { NA } \\
\text { NA } \\
\text { NA } \\
\text { NA } \\
\text { NA } \\
4 \cdot 85 \\
\text { NA } \\
\text { NA } \\
\text { NA } \\
\text { NA } \\
1.51 \\
\text { NA } \\
30.66 \\
22 \cdot 39 \\
3.95 \\
2.43 \\
\text { NA } \\
4.04 \\
2.50 \\
0.67 \\
5.98 \\
2.30\end{array}$ & $\begin{array}{l}- \\
127 \\
125 \\
152 \\
165 \\
\\
99 \\
40 \\
- \\
184 \\
130\end{array}$ & $\begin{array}{r}0-244 \\
\\
90-174 \\
83-181 \\
56-331 \\
45-422 \\
\\
27-253 \\
1-223 \\
0-555 \\
92-329 \\
27-380\end{array}$ & $\begin{array}{r}77 \cdot 13 \\
20.42 \\
0.72 \\
1.64 \\
1.28 \\
0.76 \\
0.73 \\
1.49 \\
5.19 \\
1.95 \\
0.70 \\
0.91 \\
0.56 \\
1.59 \\
0.86 \\
35.92 \\
25.65 \\
4.80 \\
4.01 \\
1.98 \\
4.84 \\
2.88 \\
0.83 \\
6.39 \\
2.47\end{array}$ & $\begin{array}{c}108 \\
108 \\
279 \\
122 \\
156 \\
131 \\
137 \\
67 \\
77 \\
204 \\
285 \\
180 \\
- \\
109 \\
109 \\
125 \\
100 \\
101 \\
82 \\
35 \\
172 \\
122\end{array}$ & $\begin{array}{c}87-135 \\
67-163 \\
34-1009 \\
15-442 \\
19-563 \\
3-730 \\
3-765 \\
2-373 \\
21-197 \\
56-524 \\
34-1031 \\
0-403 \\
4-1004 \\
0-232 \\
0-429 \\
77-148 \\
73-158 \\
46-272 \\
27-255 \\
12-366 \\
22-212 \\
1-194 \\
0-444 \\
86-308 \\
25-355\end{array}$ \\
\hline
\end{tabular}

with adjustment for occupational activity, the adjustment being specific for cause of death and age group, but approximative with regard to effects from calendar time and geographical area.

The reference rates for the incidence of cancer were based on national statistics. ${ }^{22}$

\section{Results}

The total mortality among the gas workers was increased, 84 deaths were observed whereas 67 would be expected, based on the reference rates for occupationally active men (table 2 ). The excess was mainly caused by increased risks for circulatory diseases and violent deaths. No excess of total cancer mortality or lung cancer mortality was found. The violent deaths were not related to the work environment.

The excess of circulatory diseases was mainly due to an excess after long follow up, more than 40 years from start of employment, thus indicating that it may be related to occupational factors (table 3 ).

There was an excess of respiratory diseases after long follow up, based on small numbers, however.

An analysis of the SMR by duration of employment (table 4) showed an excess of circulatory diseases among those employed for more than 30 years but not among those employed for shorter periods.

The analysis of the mortality by department should be interpreted with caution, since the expected numbers of deaths in each department were small and since the changing of job types could not be traced for the period before 1965. There was an excess of circulatory diseases among the workshop and maintenance workers and an excess of violent deaths among the outside workers (table 5). There were no excesses among the coke oven workers.

In general, the analysis of the incidence of cancer (table 6) supported the findings in the mortality

Table 3 Mortality during different periods of follow up. Reference rates: Occupationally active men in Stockholm

\begin{tabular}{|c|c|c|c|c|c|c|c|c|c|c|c|c|}
\hline \multirow[b]{3}{*}{ Cause of death (ICD 8) } & \multicolumn{12}{|c|}{ Follow up period $(y)$} \\
\hline & \multicolumn{4}{|c|}{$1-19$} & \multicolumn{4}{|c|}{$20-39$} & \multicolumn{4}{|l|}{$\geqslant 40$} \\
\hline & Obs & $\operatorname{Exp}$ & $S M R$ & $95 \% C I$ & Obs & $\operatorname{Exp}$ & $S M R$ & $95 \% \mathrm{CI}$ & Obs & $\operatorname{Exp}$ & $S M R$ & $95 \% C I$ \\
\hline All causes $(0-999)$ & 20 & $16 \cdot 5$ & 122 & $74-188$ & 38 & $34 \cdot 5$ & 110 & $78-151$ & 26 & $15 \cdot 3$ & 170 & $11-249$ \\
\hline $\begin{array}{l}\text { All malignant tumours }(140-209) \text { : } \\
\text { Lung cancer }(162) \\
\text { Circulatory diseases }(390-458) \text { : } \\
\text { Ischaemic heart disease }(410-414) \\
\text { Respiratory diseases }(460-519) \\
\text { Violent death and intoxication (E800-E999) }\end{array}$ & $\begin{array}{l}4 \\
1 \\
9 \\
7 \\
1 \\
4\end{array}$ & $\begin{array}{l}4 \cdot 2 \\
1 \cdot 0 \\
6 \cdot 5 \\
4 \cdot 7 \\
0 \cdot 5 \\
2 \cdot 7\end{array}$ & $\begin{array}{r}94 \\
98 \\
138 \\
149 \\
198 \\
146\end{array}$ & $\begin{array}{r}26-241 \\
2-544 \\
63-252 \\
60-307 \\
5-1100 \\
40-374\end{array}$ & $\begin{array}{r}12 \\
2 \\
15 \\
11 \\
0 \\
7\end{array}$ & $\begin{array}{r}10 \cdot 3 \\
2 \cdot 6 \\
16 \cdot 2 \\
12 \cdot 0 \\
1 \cdot 2 \\
2 \cdot 7\end{array}$ & $\begin{array}{r}116 \\
76 \\
93 \\
91 \\
\frac{263}{16}\end{array}$ & $\begin{array}{r}60-203 \\
9-273 \\
52-153 \\
46-164 \\
0-304 \\
106-541\end{array}$ & $\begin{array}{r}6 \\
1 \\
15 \\
10 \\
3 \\
0\end{array}$ & $\begin{array}{l}4 \cdot 8 \\
1 \cdot 2 \\
7 \cdot 9 \\
5 \cdot 7 \\
0 \cdot 7 \\
0 \cdot 6\end{array}$ & $\begin{array}{r}126 \\
84 \\
189 \\
176 \\
426 \\
-\end{array}$ & $\begin{array}{r}46-275 \\
2-470 \\
106-312 \\
85-325 \\
88-1244 \\
0-642\end{array}$ \\
\hline
\end{tabular}


Table 4 Mortality by duration of employment. Reference rates: occupationally active men in Stockholm. Observation of risk started 30 years after first employment ( 30 years of latency)

\begin{tabular}{|c|c|c|c|c|c|c|c|c|}
\hline \multirow[b]{3}{*}{ Cause of death (ICD 8) } & \multicolumn{8}{|c|}{ Employment period $(y)$} \\
\hline & \multicolumn{4}{|l|}{$1-29$} & \multicolumn{4}{|c|}{$\geqslant 30$} \\
\hline & Obs & $\operatorname{Exp}$ & $S M R$ & $95 \% C I$ & Obs & $\operatorname{Exp}$ & $S M R$ & $95 \% \mathrm{CI}$ \\
\hline All causes (0-999) & 17 & $16 \cdot 6$ & 103 & $60-164$ & 30 & $18 \cdot 1$ & 166 & $112-236$ \\
\hline $\begin{array}{l}\text { All malignant tumours (140-209): } \\
\text { Lung cancer }(162) \\
\text { Circulatory diseases }(390-458) \text { : } \\
\text { Ischaemic heart disease }(410-414)\end{array}$ & $\begin{array}{l}4 \\
0 \\
7 \\
5\end{array}$ & $\begin{array}{l}5 \cdot 2 \\
1 \cdot 3 \\
8 \cdot 3 \\
6 \cdot 1\end{array}$ & $\begin{array}{c}77 \\
84 \\
81\end{array}$ & $\begin{array}{r}21-198 \\
0-279 \\
34-174 \\
26-190\end{array}$ & $\begin{array}{r}8 \\
2 \\
16 \\
11\end{array}$ & $\begin{array}{l}5 \cdot 6 \\
1 \cdot 4 \\
9 \cdot 2 \\
6 \cdot 6\end{array}$ & $\begin{array}{l}143 \\
141 \\
175 \\
167\end{array}$ & $\begin{array}{r}62-282 \\
17-509 \\
100-284 \\
83-299\end{array}$ \\
\hline
\end{tabular}

analysis. Two rare tumours were found; one nasal cancer and the other sinonasal cancer.

\section{Discussion}

There was an increased mortality from circulatory diseases and violent deaths among the gas workers. The possible causes, the effects of smoking habits, and choice of reference population are discussed below.

\section{CIRCULATORY DISEASES}

The mortality from circulatory diseases, including ischaemic heart disease, was increased in the cohort and the increase was more pronounced after long follow up and after a long employment period. This supports that the excess was caused by occupational factors.

An increased risk of ischaemic heart disease has been reported also in other groups exposed to combustion products, and animal experimental data suggest that PAH may be the causative factor. ${ }^{23}{ }^{24}$ In addition, it has been proposed that the atherosclerotic plaque is a benign smooth muscle neoplastic tumour. ${ }^{25} \mathrm{~A}$ recent study showed the presence of a transforming gene in human atherosclerotic plaque DNA, indicating that somatic cell-gene alterations play a part in atherosclerotic plaque development. ${ }^{26}$

The largest excess of ischaemic heart disease was found among the workshop and maintenance workers and not among the coke oven workers. The coke oven workers had considerably shorter employment periods, however, and their cumulated exposure to PAHs may have been lower than that for the work- shop and maintenance workers. No definite conclusions may be formulated since exposure data are lacking.

The study was limited to workers employed for at least one year between 1965 and 1972. In 1965 the plant had already been operating for a long time and many of the gas workers had started their employment earlier. This leads to a lack of individuals with short employment periods in the cohort and since the long term employed workers are a "surviving" population the risks may be underestimated. ${ }^{27}$

An excess of ischaemic heart disease was also found among coke oven workers at a Swedish steel plant, ${ }^{12}$ although no excess has been reported among coke oven workers or gas workers in the United States ${ }^{5-8}$ or United Kingdom. ${ }^{29}$ Lack of smoking data and possible bias from the healthy worker effect make direct comparisons difficult, however..$^{28}$

\section{OTHER CAUSES OF DEATH}

There were indications of an excess of respiratory diseases after long follow up, with three observed cases whereas 0.7 would be expected. The high exposure to dust may have played a part, although no conclusions can be based on only three cases.

\section{CANCER INCIDENCE AND MORTALITY}

There were two cases of nasal and sinonasal cancer whereas only 0.07 would be expected. An association with exposure to chemicals in the workplace could be explained by deposition in the nasal mucosa of dust particles of large diameters coated with PAH.

Table 5 Mortality from 1966 to 1986 by department. Reference rates: occupationally active men in Stockholm

\begin{tabular}{|c|c|c|c|c|c|c|c|c|c|c|}
\hline \multirow[b]{2}{*}{ Cause of death } & \multicolumn{3}{|c|}{ Coke ovens } & \multicolumn{3}{|c|}{ Steam and generator } & \multicolumn{3}{|c|}{ Coke department } & \multirow{2}{*}{$\begin{array}{l}\text { Q } \\
\frac{\mathrm{C}}{\mathbb{D}} \\
\stackrel{+}{+}\end{array}$} \\
\hline & Obs & $\operatorname{Exp}$ & $S M R$ & Obs & $E x p$ & $S M R$ & Obs & $\operatorname{Exp}$ & $S M R$ & \\
\hline All causes & 13 & $12 \cdot 2$ & 106 & 3 & $3 \cdot 1$ & 98 & 14 & $10 \cdot 0$ & 140 & $\frac{0}{0}$ \\
\hline $\begin{array}{l}\text { All malignant tumours } \\
\text { Lung cancer } \\
\text { Haematopoietic organs } \\
\text { Circulatory disease } \\
\text { Ischaemic heart disease } \\
\text { Respiratory diseases } \\
\text { Violent death }\end{array}$ & $\begin{array}{l}5 \\
0 \\
0 \\
4 \\
3 \\
0 \\
3\end{array}$ & $\begin{array}{l}3 \cdot 5 \\
0 \cdot 9 \\
0 \cdot 3 \\
5 \cdot 5 \\
4 \cdot 0 \\
0 \cdot 4 \\
1 \cdot 2\end{array}$ & $\begin{array}{l}\frac{143}{-} \\
72 \\
\frac{74}{241}\end{array}$ & $\begin{array}{l}2 \\
0 \\
0 \\
0 \\
0 \\
0 \\
1\end{array}$ & $\begin{array}{l}0 \cdot 9 \\
0 \cdot 2 \\
0 \cdot 1 \\
1 \cdot 4 \\
1 \cdot 0 \\
0 \cdot 1 \\
0 \cdot 3\end{array}$ & $\begin{array}{l}222 \\
- \\
\overline{-} \\
\overline{3}\end{array}$ & $\begin{array}{l}6 \\
2 \\
0 \\
6 \\
4 \\
1 \\
1\end{array}$ & $\begin{array}{l}2 \cdot 8 \\
0 \cdot 7 \\
0 \cdot 2 \\
4 \cdot 5 \\
3 \cdot 3 \\
0 \cdot 4 \\
1 \cdot 0\end{array}$ & $\begin{array}{r}211 \\
284 \\
133 \\
122 \\
276 \\
95\end{array}$ & 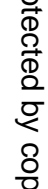 \\
\hline
\end{tabular}


Table 6 Incidence of cancer among the gas production workers 1966-83. Reference rates based on national statistics (4521 person-years of observation)

\begin{tabular}{lrrrc}
\hline Cancer site (ICD 7) & Obs & Exp & $S M R$ & $95 \% C I$ \\
\hline All malignant tumours (140-209) & 26 & $23 \cdot 88$ & 109 & $71-159$ \\
Oesophagus (150) & 2 & 0.34 & 580 & $70-2097$ \\
Stomach (151) & 1 & $1 \cdot 70$ & 59 & $1-328$ \\
Colon (153) & 3 & $1 \cdot 65$ & 181 & $37-530$ \\
Rectum (154) & 1 & $1 \cdot 22$ & 82 & $2-456$ \\
Liver (155) & 2 & $0 \cdot 61$ & 329 & $39-1189$ \\
Pancreas (157) & 1 & 0.95 & 106 & $2-589$ \\
Nose and nasal sinuses (160) & 2 & $0 \cdot 07$ & 2957 & $357-10689$ \\
Lung (162) & 4 & $2 \cdot 95$ & 135 & $36-346$ \\
Prostate (177) & 3 & $4 \cdot 20$ & 71 & $14-209$ \\
Kidney (180) & 1 & $1 \cdot 18$ & 84 & $2-470$ \\
Bladder (181) & 2 & 1.68 & 119 & $14-431$ \\
Nervous system (193) & 2 & 0.81 & 247 & $29-894$ \\
Haematopoietic organs (200-209) & 1 & $2 \cdot 02$ & 49 & $1-275$ \\
\hline
\end{tabular}

Increased risks for nose and sinonasal cancer have been found among wood (furniture) workers, ${ }^{30-32}$ but not among gas or coke oven workers.

Neither the incidence nor the mortality of lung cancer was increased. This agrees with the findings in the Swedish cohort of coke oven workers ${ }^{12}$ but deviates from the excess found among coke oven workers in the United States.

The reason for the normal rate of lung cancer is obscure. The explanation for the non-positive findings may be the high turnover rate of the workforce at the coke ovens, leading to a comparatively low cumulated dose of PAHs. The number of expected cases was small and chance may also have contributed to the normal finding.

\section{SMOKING HABITS}

Fifty two per cent of the workshop and maintenance workers were daily smokers. The smoking habits in a sample of the Swedish population comprising 55000 subjects were investigated in $1963 .{ }^{33}$ In large cities in ages $18-4957 \%$ were daily smokers and in ages $50-69$ $56 \%$ were smokers. Although a different method was used for collecting data in our study, it seems as if the workshop and maintenance workers had smoking habits similar to those in the reference population and the excess of circulatory diseases does not seem to be caused by tobacco smoking.

\section{REFERENCE RATES FOR MORTALITY}

The SMRs based on occupationally active men as referents were derived to reduce the bias from the healthy worker effect. ${ }^{21}$ The error introduced by the approximations seem to be small and the magnitude of the healthy worker effect was similar to what has been found in other studies. ${ }^{34}$ These rates have been given preference in the evaluation.

We acknowledge the help of Sven Lindqvist, Eliana Alvarez, Bo Jansson, and Rolf Wiren at the Stockholm Energy Company. We thank Professor Christer Hogstedt for valuable advice and improvements of the manuscript and research assistant Annika Gustavsson for computer work.

The investigation was supported by a grant from the Swedish Work Environment Fund (project No 870085) and was also financially supported by the Stockholm Energy Company.

Requests for reprints to: Dr P Gustavsson, Department of Occupational Medicine, Karolinska Hospital, S-104 01 Stockholm, Sweden.

1 Kuroda S, Kawahata K. Über die gewerbliche Entstehung des Lungenkrebses bei Generatorgasarbeitern: Zeitschrift für Krebsforschung 1936;45:36-9.

2 Doll R, Vessey P, Beasley RWR, et al. Mortality of gasworkers: final report of a prospective study. $B r J$ Ind Med 1972;29: $394-406$.

3 Stagis Hansen K, Viskum S, Spang Pedersen M. Dödelighed blandt gasvaerksarbejdere [Mortality among gas production workers]. Ugeskr Laeger 1986;148:610-2.

4 International Agency for Research on Cancer. Monographs on the evaluation of the carcinogenic risk of chemicals to humans. Vol 34 Polynuclear aromatic compounds. Part 3. Lyon: IARC 1984.

5 Lloyd JW. Long term mortality study of steelworkers. V. Respiratory cancer in coke plant workers. J Occup Med 1971;13:53-68.

6 Redmond CK, Giocco A, Lloyd JW, Rush HW. Long-term mortality study of steelworkers. VI. Mortality from malignant neoplasms among coke oven workers. J Occup Med 1972;14:621-9.

7 Redmond CK, Strobino BR, Cypess RH. Cancer experience among coke by-product workers. Ann NY Acad Sci 1976;271:102-15.

8 Redmond CK. Cancer mortality among coke oven workers. Environ Health Perspect 1983;52:66-73.

9 Hurley JF, Archibald R, Collings PL, Fanning DM, Jacobsen $\mathrm{M}$, Steele RC. The mortality of coke workers in Britain. $\mathrm{Am} \mathrm{J}$ Ind Med 1983;4:691-704.

10 Bertrand JP, Chau N, Patris A, et al. Mortality due to respiratory

\begin{tabular}{|c|c|c|c|c|c|c|c|c|c|c|c|}
\hline \multicolumn{3}{|c|}{ Byproduct department } & \multicolumn{3}{|c|}{ Workshop E maintenance } & \multicolumn{3}{|c|}{ Outside workers } & \multicolumn{3}{|c|}{ Sample preparation } \\
\hline 4 & $6 \cdot 2$ & 65 & 36 & 25.9 & 139 & 12 & 8.6 & 140 & 3 & 1.4 & 219 \\
\hline
\end{tabular}


cancers in the coke oven plants of the Lorraine coalmining industry (Houilleres du Bassin de Lorraine). $\mathrm{Br} \mathrm{J}$ Ind Med $1987 ; 44: 559-65$.

11 Axelson O, de Verdier A, Sundell L, Tallgren U. Mortalitetsmönstret hos anställda vid svenskt koksverk (The mortality pattern among employees at a Swedish coke-oven works). Nordisk Företagshälsovård 1979;2:5-12.

12 Ahlborg C jr, Hillert L, Tallgren U. Dödsorsaker och cancersjuklighet bland anställda vid ett koksverk (Mortality and cancer incidence among employees in a coke plant). Proceedings from the Swedish Society of Medicine. Hygiea 1987;96:134.

13 Hogstedt C, Andersson K, Frenning B, Gustavsson A. A cohort study on mortality among long-time employed Swedish chimney sweeps. Scand J Work Environ Health 1982;8:72-8 (suppl 1).

14 Gustavsson P, Gustavsson A, Hogstedt C. Excess mortality among Swedish chimney sweeps. Br J Ind Med 1987;44: 738-43.

15 Hansen E. Mortality from cancer and ischemic heart disease in Danish chimney sweeps: a five-year follow up. Am J Epidemiol 1983;117:160-4.

16 MacLaren WM, Hurley JF. Mortality of tar distillation workers. Scand J Work Environ Health 1987;13:404-11.

17 Theriault GP, Tremblay CG, Armstrong BG. Risk of ischemic heart disease among primary aluminium production workers. Am J Ind Med 1988;13:659-66.

18 Lindstedt G, Sollenberg J. Polycyclic aromatic hydrocarbons in the occupational environment. Scand JWork Environ Health 1982;8:1-19.

19 Marsh GM, Preininger M. OCMAP: a user-oriented occupational cohort mortality analysis program. American Statistician 1980;34:245.

20 Andersson K, Anjou CG, Brodin G, Kling H, Samuelsson PJ. Datain, Ratin, Cohort, Search, Stat Datorprogram for kohortstudier. Användarhandledning (Datain, Ratin, Cohort, Search, Stat Computer programs for cohort studies. User manual). Linköping: Linköping University. 1982.

21 Swedish National Central Bureau of Statistics. Dödsfallsregister 1961-1979 (Registry of deaths 1961-1979.) Stockholm: SCB, 1982:5.
22 National Board of Health and Welfare. Cancer incidence in Sweden 1958-1983. Stockholm: Cancer Registry, 1958-83.

23 Albert RE, Vanderlaan M, Burns FJ, Nishizumi M. Effect of carcinogens on chicken atherosclerosis. Cancer Res 1977;37:2232-5.

24 Bond JA, Gown AN, Yang HL, Benditt EP, Juchau MB. Further investigations of the capacity of polynuclear aromatic hydrocarbons to elicit atherosclerotic lesions. J Toxicol Environ Health 1981;7:327-35.

25 Benditt EP, Benditt HJN. Evidence for a monoclonal origin of human atherosclerotic plaques. Proc Natl Acad Sci USA 1973;70:1753-6.

26 Penn A, Garte SJ, Warren L, Nesta D, Mindich B. Transforming gene in human atherosclerotic plaque DNA. Proc Natl Acad Sci USA 1986;83:7951-5.

27 Johnson ES, Matanoski GM. SMR estimations in "prevalent" cohorts and "incident" cohorts. Med Lav 1987;78:263-71.

28 Fox AJ, Collier PF. Low mortality rates in industrial cohort studies due to selection for work and survival in the industry. Br J Prev Soc Med 1976;30:225-30.

29 McMichael AJ. Standardised mortality ratios and the "healthy" workers effect." Scratching beneath the surface. J Occup Med 1976;18:165-8.

30 Acheson ED, Cowdell RH, Hadfield E, Macbeth RG. Nasal cancer in woodworkers in the furniture industry. $\mathrm{Br}$ Med J 1968;ii:587-96.

31 Gerhardsson MR, Norell SE, Kiviranta HJ, Ahlbom A. Respiratory cancer in furniture workers. $\mathrm{Br} J$ Ind $\mathrm{Med}$ $1985 ; 42: 403-5$.

32 Hernberg S, Westerholm P, Schultz-Larsen K, et al. Nasal and sinonasal cancer. Connection with occupational exposures in Denmark, Finland and Sweden. Scand JWork Environ Health 1983;9:315-26.

33 Swedish Central Bureau of Statistics. Rökvanor i Sverige (Smoking habits in Sweden). Stockholm, SCB, 1965.

34 Vinni $K$, Hakama $M$. Defining expected mortality in occupational studies. Scand J Work Environ Health 1979;5:297-303.

Accepted 5 May 1989

\section{Destruction of manuscripts}

From 1 July 1985 articles submitted for publication will not be returned. Authors whose papers are rejected will be advised of the decision and the manuscripts will be kept under security for three months to deal with any inquiries and then destroyed. 